\title{
Kjeld Erik Brodsgaard and Zheng Yongnian (eds.), The Chinese Communist Party in Reform
}

London, Routledge, 2006, 268 pp.

\section{Wu Guoguang}

\section{OpenEdition}

\section{Journals}

Electronic version

URL: http://journals.openedition.org/chinaperspectives/3173

DOI: 10.4000/chinaperspectives.3173

ISSN: 1996-4617

\section{Publisher}

Centre d'étude français sur la Chine contemporaine

Printed version

Date of publication: 1 November 2006

Number of pages: 71-72

ISSN: 2070-3449

\section{Electronic reference}

Wu Guoguang, « Kjeld Erik Brodsgaard and Zheng Yongnian (eds.), The Chinese Communist Party in Reform », China Perspectives [Online], 68 | november- december 2006, Online since 06 January 2009, connection on 24 September 2020. URL : http://journals.openedition.org/chinaperspectives/3173 ; DOI : https://doi.org/10.4000/chinaperspectives.3173

This text was automatically generated on 24 September 2020 .

(c) All rights reserved 


\section{Kjeld Erik Brodsgaard and Zheng Yongnian (eds.), The Chinese Communist Party in Reform}

London, Routledge, 2006, 268 pp.

\section{Wu Guoguang}

1 Although China has undergone profound changes since economic reforms and marketisation were introduced in the late 1970s, the Chinese Communist Party (CCP) still represents a niche surviving from before this period, not only in politics but also in many other dimensions of life in China. This simple fact has for a long time been virtually ignored, intentionally or not, in academic studies on China, as most of the energy in the field is, reasonably, devoted to following the fast-changing reforms that are expected to reduce the importance of the CCP. These expectations are not entirely

2 wrong, as the CCP itself is now reported to be under reform; they are not accurate, however, as the Party carries out reforms simply for the sake of maintaining and even strengthening its unchallenged ruling position, rather than in order to open the political market for the party competition and popular participation that are often assumed to accompany economic marketisation. In this context, how can one assess the CCP today and its efforts to adapt, while keeping its monopoly on ruling post-economic reform China? The volume under review is a timely contribution to answering this question.

3 The contributors, who are all Western-trained scholars, despite their diverse ethnic and personal backgrounds, mostly living in the Asia-Pacific region and Europe (for readers' possible curiosity, only one contributor is based in the United States), are well qualified to discuss the theme and, in particular, their respective sub-topics. The 12 individual chapters are effectively organised to address three important dimensions of the CCP's relevance to China today: the Party's role in the country's economic, social and political development; the Party's own organisational adjustment to the modern governance of a transitional society; and the apparatus and operation of the Party 
machine. Many of the chapters are well researched, though some are less wellgrounded than others.

4 Andrew Walder's chapter analyses China within the broader comparative context with other former communist regimes, and examines the mobility patterns of China's political elite with a sociological perspective. His conclusion defines the optimistic tone that many contributors to the volume share: the CCP can be an agent, rather than a target, of China's future political change.

5 A veteran China expert specialised in the nomenklatura system, John Burns comes back to his own territory in this volume, and finds that, in spite of profound contextual changes, the CCP's organisation shows "striking continuities" with the past. As he also focuses on the Party elite, but with a more institutional perspective, Burns' cautious argument about the future of the Party is valuable and effectively balances Walder's line of reasoning.

6 You Ji and Zou Keyuan turn their investigations to the two pillars that support the CCP regime: You is concerned with the old-fashioned gun barrel, namely, the PLA, and argues that a transition of its relationship with the CCP has taken place in the 1990s; Zou's topic is an instrument of modern governance: the law, and tremendous Party control over legislation and jurisdiction are identified and discussed in depth. The comparison between these two chapters represents a typical intricacy in studies of ongoing China: when one looks at those realms where the CCP remains predominant, some new developments there can be surprisingly attractive; in those areas one assumes the Party is declining, however, the real mechanism can be still the old machine with some new decorations.

7 The three following chapters concern the Party's cadre management and education systems. Kjeld Brodsgaard chooses a micro-case study of Yangpu Economic Development Zone in Hainan Province and, through the lens of the bianzhi system, confirms that the Party firmly controls governmental administration through cadre management. Maria Heimer studies the cadre responsibility system to look at how the Party implements its well-intentioned policies such as "people-oriented" and "balanced development" approaches to China's modernisation. Her conclusion is a mixed reflection on the Party's adjustment to reforms. Ignatius Wibowo and Lye Liang Fook's chapter also emphasises the Party's adaptability, as exemplified by cadre education reform at the Central Party School.

8 Moving to the societal level, at which the Party is also struggling to revitalise its connections with various social groups, two chapters of the book are devoted to examining its relationship with the urban working class, leaving aside the Party's relations with other significant social forces such as farmers and entrepreneurs. In their chapter, Takahara Akio and Robert Benewick find the Party plays a significant role in urban communities, but it is also confronted with various challenges arising from marketisation. Cai Yonghsun's discussion of workers' power depicts a situation that contradicts the claims of the CCP: while the Party traditionally defines itself as "the vanguard of the working class", and the reformed Party boasts the economic benefits it brings to everyone, the working class in today's China in fact suffers from a great status decline both in terms of political power and welfare provision. The implications of these studies are complex, somewhat in contrast with some previous chapters that try to portray a CCP "making progress with passing time" (yushi jujin), as claimed by the Party itself. The Party is able to reaffirm its control of and penetration 
into Chinese society, but this capacity is not necessarily a positive adjustment to postmarketisation reform China; the Party's embrace of the new rich is widely applauded, but cannot be seen as progressive if this step estranges the Party, the only effective channel for articulating and incorporating different interests, from the working class and farmers, the majority of Chinese population.

9 To achieve "balanced" progress, political democratisation should be placed on the agenda. Will the CCP be democratised? Will the CCP support China's democratisation? The last three chapters examine these questions from different angles. He Baogang regards intra-party democracy as a hope, but his empirical evidence from which he draws support to the argued "hope" is really thin. Chien-min Chao and Yeau-tarn Lee discuss how the Taiwanese transition from one-party regime to democracy can be a model for China. Zheng Yongnian situates the CCP within the broader context of China's democratic transformation as a nation, providing a comprehensive analysis of class-relations in today's China and their impact for future democratisation. In sum, this is a well-edited volume, which definitely contributes much to the ongoing debate on how to assess China's political change and what role the CCP plays in this change. 